CHAPTER VI

REPORT OF COMMISSIONS 


\section{Commission 4: Ephemerides}

President: B.D. Yallop

Secretary: C.Y. Hohenkerk

Commission 4 held one business meeting.

Business Meeting, August 19: During the triennium two members had died, Clayton Smith and Claus Osterwinter. A tribute was made to the Commission's deceased member, Clayton Smith.

The officers elected for Commission 4 for 1994 to 1997 are President, H. Kinoshita and Vice President, E.M. Standish.

The following membership of the organising committee was approved:
V.K. Abalakin
T. Fukoshima
G.A. Krasinsky
P.K. Seidelmann
J.-E. Arlot
He Miao-Fu
J.H. Leiske
B.D. Yallop
J. Chapront
G.H. Kaplan
H. Schwan

The following new members were elected:
Prof Wong Toian-Yi
J.L. Hilton
W. Thuillot
C.Y Hohenkerk

The following consultants were approved:
R.A. McCutcheon
J.A. Bangert

J. Meeus

The Newsletter. The President said that he had followed a tradition started by Bruno Morando by issuing two more newsletters. Members responses to questions raised on restructuring of the IAU had convinced him that he could legitimately represent members views. Members were quick to report errors concerning address information, but it would help if they volunteered certain information, for example on recently acquired e-mail addresses. $H$. Kinoshita said that he intended to continue the newsletter during his Presidency and would try to widen its scope.

Restructuring the IAU. The President described the basis of the new proposals. The latest suggestion was to keep the Commissions intact and to introduce a Divisional Structure above the Commissions. There being fewer Division Presidents than Commission Presidents this would improve interaction between the Executive Committee and Division Presidents, and hence indirectly the rest of the IAU. The President felt that if we did not accept the new proposal the consequences could be worse and members should take this opportunity to have their ideas incorporated into the new structure.

Several members spoke in favour of the new proposals. J.O. Dickey said that she thought that the restructuring was a good idea. The IAG had a similar structure which produced better communication between members, groups and the executive. This positive element encouraged the younger members to take more interest in IAG affairs. I. Meuller agreed with restructuring the IAU. The IUGG had already restructured successfully. He felt that the system should be made as flexible as possible with about ten main areas having Presidents who would run the IAU. Commissions should be able to join more than one division if they so wished. B. Kolaczek showed a view graph consisting of only seven divisions which most members preferred. J.H. Leiske said it was vital that the IAU have Division Presidents on the Executive Committee and that they have full voting rights. The meeting agreed with this proposal. G.A. Wilkins regretted that there was no formal proposal with documentation to put before all the members of the IAU. B. Kolaczek reminded the meeting that nothing could be implemented until the next General Assembly in three years time, so there was ample time. 
Resolutions concerning the Commission. The President pointed out that Commission 4 was a co-supporting commission to JD8, JD14, JD19, Symposium 166, and WGM2, which were producing resolutions. In previous General Assemblies there had always been time to discuss resolutions. I. Meuller said that if anyone has a resolution pass it on to B.D. Yallop and the Resolutions Committee for them to deal with before the closing ceremony.

IAU/IAG/COSPAR Working Group on Cartographic Coordinates and rotational Elements of Planets and Satellites, August 23. The report of the Working Group was given by M.E Davies,. Special attention was given to data that had been revised since the previous report. There was a lively discussion on coordinate systems and the origin of cartographic coordinates used on planetary maps. The session was held jointly with Commission 16. 